Article

\title{
Effects of Metamitron under Different Relative Humidity Conditions on the Fruit Abscission of Malus domestica Borkh. Cultivars
}

\author{
Nídia Rosa ${ }^{1, *}$, Wim Verjans ${ }^{2}$, Glória Àvila ${ }^{3}$, Joaquim Carbó ${ }^{3}$, Joan Bonany ${ }^{3}{ }^{(0)}$, \\ José Cochicho Ramalho ${ }^{4,5, * \mathbb{D}}$, Luís Asín ${ }^{6, *}$ and Cristina Moniz Oliveira ${ }^{1, * \mathbb{D}}$ \\ 1 Linking Landscape, Environment, Agriculture and Food (LEAF), Instituto Superior de Agronomia (ISA), \\ Universidade de Lisboa, 1349-017 Lisbon, Portugal \\ $2 \quad$ PCFruit Research Station, BE-3800 Sint-Truiden, Belgium; wim.verjans@pcfruit.be \\ 3 IRTA-Mas Badia, 17134 La Tallada, Spain; gloria.avila@irta.cat (G.À.); joaquim.carbo@irta.cat (J.C.); \\ joan.bonany@irta.cat (J.B.) \\ 4 PlantStress \& Biodiversity Lab, Centro de Estudos Florestais (CEF), Instituto Superior Agronomia (ISA), \\ Universidade de Lisboa, 1349-017 Lisboa, Portugal \\ 5 Unidade de Geobiociências, Geoengenharias e Geotecnologias (GeoBioTec), \\ Faculdade de Ciências e Tecnologia, Universidade Nova de Lisboa, 2829-516 Caparica, Portugal \\ 6 IRTA Fruitcentre, PCiTAL, Park of Gardeny, Fruitcentre Building, 25003 Lleida, Spain \\ * Correspondence: nidia.heleno.rosa@gmail.com (N.R.); cochichor@isa.ulisboa.pt (J.C.R.); \\ luis.asin@irta.cat (L.A.); crismoniz@isa.ulisboa.pt (C.M.O.)
}

Received: 16 October 2020; Accepted: 20 November 2020; Published: 23 November 2020

\begin{abstract}
Metamitron is an apple (Malus domestica Borkh.) fruit thinner that acts by reducing the photosynthetic capacity of trees. Relative humidity may influence thinning efficacy; however, the broadness of this effect is not yet fully understood. Trials were set in Sint-Truiden (Belgium) in 2018 and Lleida and Girona (Spain) in 2019, using 4-year-old cvs. Braeburn and Elstar trees in Belgium, and 16-year-old cv. Golden Reinders trees in Spain. Four treatments were implemented at the stage of 12-14 mm fruit diameter: (a) CTR — control, trees under natural environmental conditions; (b) HH-high humidity, trees submitted to artificially increased air relative humidity applied for $3 \mathrm{~h}$ prior to the beginning of the experiment; (c) MET - trees sprayed with $247.5 \mathrm{mg} / \mathrm{L}$ metamitron; (d) MET + HH-trees submitted to the combination of increased humidity $(\mathrm{HH})$ and metamitron (MET) application. In Belgium, metamitron absorption by leaves was greater than in Spain. This might be related to morphological characteristics of the leaves which developed under greater natural relative humidity levels in Belgium than in Spain. Compared to MET alone, 'Braeburn' and 'Elstar' demonstrated significantly greater metamitron absorption, 59\% and $84 \%$, respectively, under MET $+\mathrm{HH}$, accompanied by declines in leaf net photosynthesis $(10 \%$ and $32 \%$, respectively) and sucrose (31\% and $26 \%$, respectively). At harvest, MET $+\mathrm{HH}$ treatment reduced yield by $24 \%$ and $32 \%$ in 'Braeburn' and 'Elstar', respectively, when compared with MET alone. A large reduction (considered over thinning) in the yield of 'Elstar' occurred. In contrast, metamitron absorption by 'Golden Reinders' using MET alone was similar to MET + HH; however, there was a slight foliar sugar reduction in the latter treatment. In addition, both treatments enhanced shoot growth and increased fruit abscission with similar improvements in fruit weight and size. In this study, high relative humidity enhanced fruit thinning efficacy under certain circumstances, such as age or genetic predisposal, which left the tree more susceptible to a negative carbohydrate balance. For instance, 'Braeburn' and 'Elstar' were easier to thin when compared to 'Golden Reinders'. In addition, this study raises a question that requires further research regarding the impact of $\mathrm{HH}$ before and after spraying as well as its effect in combination with higher temperatures.
\end{abstract}

Keywords: absorption; carbohydrate balance; photosynthesis; sucrose; sorbitol; thinning 


\section{Introduction}

Apple (Malus domestica Borkh.) growers' profits are increasingly dependent on management strategies that prioritize apple fruit quality for fresh consumption, such as fruit size, to increase the economic value of the apples. One of the most important practices to achieve good fruit size is thinning. There are several thinning techniques, although the chemical strategy is the most widely used. The efficacy of a chemical compound can change between years, orchards, and cultivars [1,2]. Thus, unveiling the factors that can directly enhance the efficacy of chemical thinners is of extreme importance to provide a practical way of predicting the effects and obtaining a result as close as possible to the optimal goal.

Metamitron, a systemic triazinone herbicide, is one of the most common thinners used in intensive apple growing systems. Metamitron acts by inhibiting photosystem (PS) II and disrupts thylakoid electron transport by blocking the electron transfer between the primary and secondary quinones of PSII [3,4], leading to the closure of the reaction centers and, ultimately, inhibiting photosynthetic carbon fixation $[3,5]$. This will restrict carbohydrate availability, causing a negative carbohydrate balance and an enhancement of fruit drop [6-9].

Shoot growth might also contribute to a negative carbohydrate balance, as during the early phase of fruit development, there is a strong competition between the vegetative parts of the tree and the fruitlets [10]. In the apple tree, shoot growth has priority over fruit growth for carbohydrate partitioning during the first 40 days after full bloom (DAFB), which strongly contributes to a greater fruit fall under high vegetative growth $[1,11,12]$. In addition, orchard-related factors, such as rootstock, tree age, vigor, bloom density, crop load, and presence of pollinators, should also be considered when deciding the thinning strategy due to their effects on carbohydrate availability $[13,14]$.

Cultivar traits can lead to different responses to thinning applications [13,15]; therefore, adjustments are often made depending on the cultivar thinning susceptibility, which can be classified as easy ('Braeburn'), average, or difficult ('Golden Reinders') to thin [16]. Associated with specific plant responses, the variability of a chemical compound's uptake is highly dependent on the meteorological conditions before, during, and after application, namely the air relative humidity [17,18].

A high relative humidity affects the drying period at the leaf surface after chemical application. The longer the drying period, the greater the chemical penetration, with the epicuticular wax and cuticle becoming softer and more predisposed to absorption $[19,20]$. In addition, a high relative humidity maintains the turgor pressure of the guard cells, keeping the stomata open, which could also allow for a greater absorption of chemicals. Absorption occurs through a diffusion process, from a more concentrated area (leaf surface) to a less concentrated area, through water with a low diffusion resistance.

If the vapor pressure deficit (VPD) on the leaf surface is low, stomatal conductance is higher [21,22], and the water gradient will facilitate the penetration of the chemical. Along with the possible entry via open stomata, the diffusion process happens rapidly $[23,24]$. Consequently, a high relative humidity may enhance metamitron absorption, and thus photosynthesis inhibition, increasing the competition between fruitlets for the reduced available photosynthates. Therefore, as glucose is necessary for sucrose and sorbitol synthesis, we hypothesized that a decrease in these sugars may be enhanced by metamitron application under high relative humidity conditions, resulting in a more pronounced thinning effect.

Meteorological conditions play a crucial role in a tree's carbon balance [25-27] and could change the efficacy of metamitron from no thinning response to over-thinning. Evaluating the interactions between relative humidity and the metamitron thinning effect is, therefore, relevant for understanding reason(s) for variable thinning efficacies, along with other aspects of the tree response through characterization of physiological and biochemical parameters for the single and combined applications of metamitron and high air relative humidity. 


\section{Materials and Methods}

\subsection{Trial Design and Plant Material}

\subsubsection{Plant Material}

In 2018, two trials were performed in Sint-Truiden, Belgium, and, in 2019, one trial was performed in Girona and one in Lleida, Spain. Trials were held in the experimental orchards of the PCFruit Research

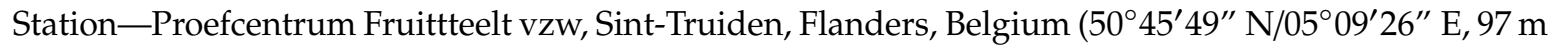
altitude), with 'Braeburn' and 'Elstar' trees in separate orchards, grafted on M9 rootstocks, planted in 2014 (4 years old), spaced $3.5 \times 1.0 \mathrm{~m}$, with 'Granny Smith' as the pollinator. The two orchards were located in the same field, side by side.

In 2019, the trials were performed in the experimental orchards of the IRTA-Lleida research

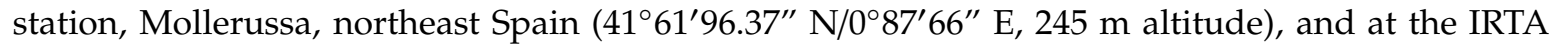
Más Badia research station, Girona, northeast Spain ( $42^{\circ} 03^{\prime} 97^{\prime \prime} \mathrm{N} / 3^{\circ} 03^{\prime} 13^{\prime \prime} \mathrm{E}, 12 \mathrm{~m}$ altitude). In both locations, 'Golden Reinders' apple trees were used, planted in 2003 (16 years old). In Lleida, the trees were grafted on M9 rootstocks, spaced $4 \times 1.4 \mathrm{~m}$, with a canopy height of $3 \mathrm{~m}$ and 'Gala Brookfield' as the pollinator, while in Girona, the trees were grafted on M9 NAKB rootstock, spaced $3.8 \times 1.1 \mathrm{~m}$, with a canopy height of $2.5 \mathrm{~m}$ and 'Granny Smith' as the pollinator. Both orchards were trained as a central leader system.

For biochemical evaluations, the leaves were quickly cleaned with a water-wet tissue before being frozen in liquid $\mathrm{N}_{2}$. All leaves were finely powdered with a mortar and pestle in liquid $\mathrm{N}_{2}$ and kept at $-80{ }^{\circ} \mathrm{C}$ until analysis.

\subsubsection{Treatment Implementation and Experimental Design}

Four treatments were implemented: (a) CTR—control, corresponding to trees under natural environmental conditions; (b) $\mathrm{HH}$-high humidity, trees submitted to artificially increased air relative humidity applied for $3 \mathrm{~h}$ prior to the beginning of the experiment; (c) MET—-trees receiving $247.5 \mathrm{mg} / \mathrm{L}$ metamitron applied as described below; (d) MET + HH-trees receiving the combination of increased air relative humidity $(\mathrm{HH})$ and metamitron $(\mathrm{MET})$ application.

The MET application was performed at a fruit diameter of 12-14 mm. All sprays were made using the recommended dose of $247.5 \mathrm{mg} / \mathrm{L}$ metamitron — as the active ingredient of Brevis ${ }^{\circledR}$ (ADAMA, Telaviv, Israel)_per $1000 \mathrm{~L} \mathrm{ha}^{-1}$, using a hand-gun sprayer. Metamitron and/or relative humidity treatments were imposed between the 29th of April and the 16th of May.

In Sint-Truiden, to raise the relative humidity, a plastic cover was placed over the trees. The relative humidity was increased by two centrifuge humidifiers of type EPA with foggers with an output of 2-20 L/hour (JDK, Sint-Truiden) placed in the middle of the area. Due to the high relative humidity outside on the application day $(65.9 \%)$, in addition to the $3 \mathrm{~h}$ of increased relative humidity prior spraying, it was also increased for $1 \mathrm{~h}$ after the metamitron was applied. In Girona and Lleida, a similar plastic cover was used, but the high relative humidity was achieved with irrigation sprinklers Super 10 (Novagric, Almeria, Spain), placed at a $1 \mathrm{~m}$ distance on both sides of the trees. The irrigation system was connected to a water tank coupled to a tractor working at 4.5 bar.

To monitor the environmental conditions in each trial, sensors for the temperature and relative humidity record were installed inside and outside the structures on both sides and in the middle (with and without $\mathrm{HH}$ ); in each case in the upper $(2 \mathrm{~m})$ and lower $(1 \mathrm{~m})$ levels of the trees. In Girona, six EasyLog USB Data Loggers (Lascar Electronics, Wiltshire, UK) were used; in Lleida, six Testo 177-h1 sensors were used (Testo, Titisee-Neustadt, Germany); and six Testo $174 \mathrm{H}$ sensors (Testo, Titisee-Neustadt, Germany USA) were used in Sint-Truiden.

The initial number of flower clusters per tree was homogeneous among treatments in each orchard. The experimental design in each orchard was a randomized complete block, with four blocks each with 
four trees per treatment in each block, in which the two central trees of each set of four were measured, for a total of eight measured trees per treatment.

\subsection{Metamitron Concentration}

Leaf samples for the metamitron and its main metabolite concentration, desamino-metamitron, were collected two days after spraying (DAS). Each sample was a pool of three shoot leaves from the top, middle, and bottom part of each tree, with one sample taken from the eastern and another from the western side of the canopy, for a total six repetitions per treatment.

Metamitron extraction was conducted according to the QuEChERS method [28] (quick, easy, cheap, effective, rugged, and safe) using $500 \mathrm{mg}$ fresh weight (FW) of frozen leaf powder and $3 \mathrm{~mL}$ of acetonitrile. The samples were shaken manually for $1 \mathrm{~min}$, after which, $1.95 \mathrm{~g}$ of extraction Supel ${ }^{\mathrm{TM}} \mathrm{QuE}$ Citrate Extraction Tube (Sigma-Aldrich, Missouri, United States of America) was added, containing $1.2 \mathrm{~g}$ of magnesium sulfate, $0.3 \mathrm{~g}$ of sodium chloride, $0.15 \mathrm{~g}$ of sodium citrate dibasic sesquihydrate, and $0.3 \mathrm{~g}$ of sodium citrate tribasic dehydrate. The samples were further shaken manually for $1 \mathrm{~min}$ and centrifuged $\left(6000 \times \mathrm{g}, 5 \mathrm{~min}, 4^{\circ} \mathrm{C}\right)$. An aliquot of $1.2 \mathrm{~mL}$ of the supernatant was transferred to a $2 \mathrm{~mL}$ Supel ${ }^{\mathrm{TM}} \mathrm{QuE}$ Verde clean-up tube (Sigma), vortexed, and further centrifuged (6000 $\mathrm{g}, 5 \mathrm{~min}$, $\left.4{ }^{\circ} \mathrm{C}\right)$. The obtained supernatant was filtered (0.45 $\mu \mathrm{m}$ filter, PTFE), and injected on a LC-MS/MS (Waters, USA). Standard curves were used for the quantification of metamitron (Sigma-Aldrich, Missouri, United States of America) and desamino-metamitron-desamino (LGC Standards, USA).

\subsection{Leaf Net Photosynthesis}

Leaf net photosynthesis measurements $\left(P_{n}\right)$ were performed in Sint-Truiden five and seven days after spraying (DAS) in recently fully developed shoot leaves at about $1.5 \mathrm{~m}$ in height with a portable Infrared Gas Analyzer (IRGA) LCi Ultra Compact Photosynthesis System (ADC BioScientific, Hoddesdon, UK), under ambient conditions of irradiance, air humidity, temperature, and $\mathrm{CO}_{2}$ supply, between 10:00 and 12:00. In each of the four blocks, one evaluation in the eastern and one in the western side of the canopy were performed, totaling eight measurements per treatment.

\subsection{Leaf Soluble Sugars}

Leaf sampling for non-structural sugar quantification was performed five and seven days after spraying (DAS) in Sint-Truiden and 2, 5, and 10 DAS, in Lleida and Girona, always between 11:00 and 12:30 h. In Sint-Truiden, six repetitions of a pool with two shoot leaves and two cluster leaves were used. In Lleida and Girona, sampling consisted of ten separate shoot leaves per treatment. The quantification of sucrose, fructose, glucose, and sorbitol was based on the method described by [29], using about $150 \mathrm{mg}$ FW frozen leaf material. The separation of sugars was performed using a Sugarpak1 column ( $300 \times 6.5 \mathrm{~mm}$, Waters) at $90^{\circ} \mathrm{C}$, with $\mathrm{H}_{2} \mathrm{O}$ (containing $50 \mathrm{mg}$ EDTA-Ca ${ }^{-1}$ ) as the eluent, at a flow rate of $0.5 \mathrm{~mL} \mathrm{~min}^{-1}$ in an HPLC system equipped with a refractive index detector (Model 2414, Waters, Milford, USA). Standard curves of each sugar were used for quantification.

\subsection{Shoot Growth}

Shoot growth was measured in Girona and Lleida using eight bourse shoots per block (total 32 shoots per treatment). The shoot length was measured on the day of metamitron application and 10 days after spraying (DAS).

\subsection{Yield Parameters}

All fruit was harvested from each tree at harvest. The number of fruit per tree, yield, fruit weight, and distribution per fruit size were determined using a commercial sorting machine (Maf Roda Agrobotic, Montauban Cedex, France). 


\subsection{Statistical Analysis}

Data were subjected to an analysis of variance, through a one-way ANOVA, to evaluate the differences between treatments on one single day after spraying, or a two-way ANOVA to evaluate the differences between the four treatments, across the several days after spraying. Means were compared by Tukey's Honestly Significant Difference (HSD) test at $\alpha=0.05$. Each ANOVA was performed independently for each of the trials. The statistical analysis was performed using Statistix 9 (Analytical Software, Tallahassee, FL, USA).

\section{Results}

\subsection{Environmental Conditions}

A brief characterization of the environmental conditions in the four trials is shown in Table 1. For the global irradiance, the night temperature before application, and the diurnal temperature on the day of application, the values were very homogeneous between the two years and locations. The average night temperature after application was always lower than $13.5^{\circ} \mathrm{C}$, although it was higher in Girona by $3^{\circ} \mathrm{C}$ compared with the other locations. The highest relative humidity increase was registered in the trial performed in Girona (35.3\%).

Table 1. Summary of the meteorological conditions in each trial: the cultivar, fruit diameter at the time of metamitron application, average of daily irradiance during 5 days after spraying (DAS) $\left(\mathrm{MJ} / \mathrm{m}^{2}\right)$, average night-time temperature from 20:00 to 8:00 h during 5 nights before and after spraying $\left({ }^{\circ} \mathrm{C}\right)$, average diurnal temperature from $8: 00$ to $20: 00 \mathrm{~h}$ on the spraying day $\left({ }^{\circ} \mathrm{C}\right)$, and average air relative humidity during the $3 \mathrm{~h}$ prior spraying (\%) in environmental conditions (Control) and high relative humidity conditions $(\mathrm{HH})$.

\begin{tabular}{|c|c|c|c|c|c|c|c|}
\hline \multirow[t]{2}{*}{$\begin{array}{l}\text { Location/ } \\
\text { Cultivar }\end{array}$} & \multirow[t]{2}{*}{$\begin{array}{l}\text { Fruit Diameter } \\
(\mathrm{mm})\end{array}$} & \multirow{2}{*}{$\begin{array}{c}\text { Global Irradiance } \\
\mathrm{MJ} / \mathrm{m}^{2}-5 \\
\text { Days After } \\
\text { Control }\end{array}$} & \multirow{2}{*}{ 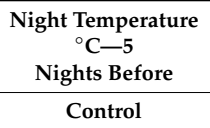 } & \multirow{2}{*}{$\begin{array}{c}\begin{array}{c}\text { Night Temperature } \\
{ }^{\circ} \mathrm{C}-5 \\
\text { Nights After }\end{array} \\
\text { Control }\end{array}$} & \multirow{2}{*}{$\begin{array}{c}\text { Diurnal Temperature } \\
{ }^{\circ} \mathrm{C} \text {-Application Day } \\
\text { Control }\end{array}$} & \multicolumn{2}{|c|}{$\begin{array}{c}\text { Relative } \\
\text { Humidity } \\
\%\end{array}$} \\
\hline & & & & & & Control & HH \\
\hline & & & 2018 & & & & \\
\hline \multirow{3}{*}{$\begin{array}{l}\text { Sint-Truiden/ } \\
\text { ‘Braeburn' } \\
\text { Sint-Truiden/ } \\
\text { 'Elstar' }\end{array}$} & $14 \pm 0.1$ & $21.7 \pm 0.6$ & $12.1 \pm 0.6$ & $9.7 \pm 0.9$ & $17.2 \pm 0.9$ & $65.9 \pm 3.6$ & $73.9 \pm 2.7$ \\
\hline & $13 \pm 0.1$ & $21.7 \pm 0.6$ & $12.1 \pm 0.6$ & $9.7 \pm 0.9$ & $17.2 \pm 0.9$ & $65.9 \pm 3.6$ & $73.9 \pm 2.7$ \\
\hline & & & 2019 & & & & \\
\hline $\begin{array}{l}\text { 'Girona/ } \\
\text { ‘Golden Reinders' }\end{array}$ & $14 \pm 0.1$ & $21.4 \pm 2.4$ & $12.0 \pm 0.9$ & $13.4 \pm 0.4$ & $16.9 \pm 0.8$ & $40.8 \pm 1.0$ & $76.1 \pm 3.7$ \\
\hline $\begin{array}{l}\text { Lleida/ } \\
\text { 'Golden Reinders' }\end{array}$ & $12 \pm 0.2$ & $21.4 \pm 1.9$ & $11.1 \pm 1.1$ & $10.3 \pm 1.1$ & $18.5 \pm 1.0$ & $44.3 \pm 1.4$ & $58.0 \pm 3.3$ \\
\hline
\end{tabular}

In Sint-Truiden, the relative humidity was increased by an average of $8 \%$ for $3 \mathrm{~h}$ prior to spraying. However, as described above, the relative humidity was also increased during the $1 \mathrm{~h}$ after spraying, from $48.6 \%$ to $68.6 \%$. Along with the relative humidity increase, there was an average temperature increase of $7.5^{\circ} \mathrm{C}$ (Figure 1). In the case of Lleida and Girona, the relative humidity was raised $13.7 \%$ and $35.3 \%$, respectively, and the temperature inside the structure was $1{ }^{\circ} \mathrm{C}$ less in both locations. 


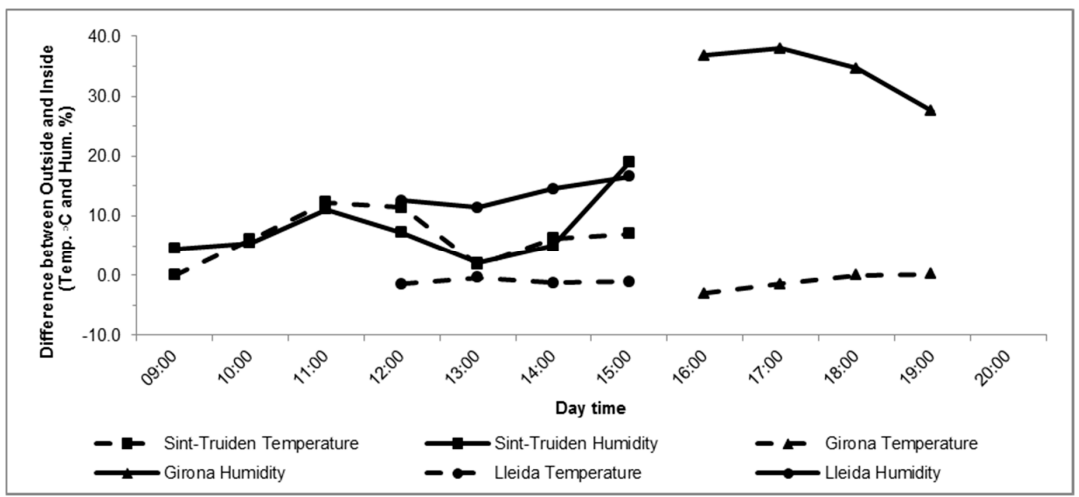

Figure 1. Difference in relative humidity and temperature between the outside and the inside of the plastic covered trees during the humidity increase period in Sint-Truiden, Belgium, in 2018 ( $\square$ ), and Girona $(\Delta)$, and Lleida $(\bullet)$, Spain, in 2019 . The solid line represents the air relative humidity $(\%)$, and the dashed line represents temperature $\left({ }^{\circ} \mathrm{C}\right)$.

\subsection{Metamitron Concentration in Leaves}

In the trials in Sint-Truiden, the increased relative humidity significantly increased the metamitron absorption $(\mathrm{MET}+\mathrm{HH}), 59 \%$ and $84 \%$, and increased desamino-metamitron formation, $49 \%$ and $58 \%$, in 'Braeburn' and 'Elstar', respectively, as compared to MET alone (Figure 2), observed by 2 DAS when the maximal absorption is expected to occur, as previously found in our preliminary experiments (data not shown). In Girona and Lleida, the metamitron and desamino-metamitron content did not significantly differ in the MET or MET + HH treatments. Metamitron absorption by 'Golden Reinders' (Lleida and Girona) was similar to that by 'Elstar' (Sint-Truiden); however, the desamino-metamitron content was higher when compared with the trials in Sint-Truiden. Among the cultivars, 'Braeburn' showed $50 \%$ higher absorption than the other cultivars.

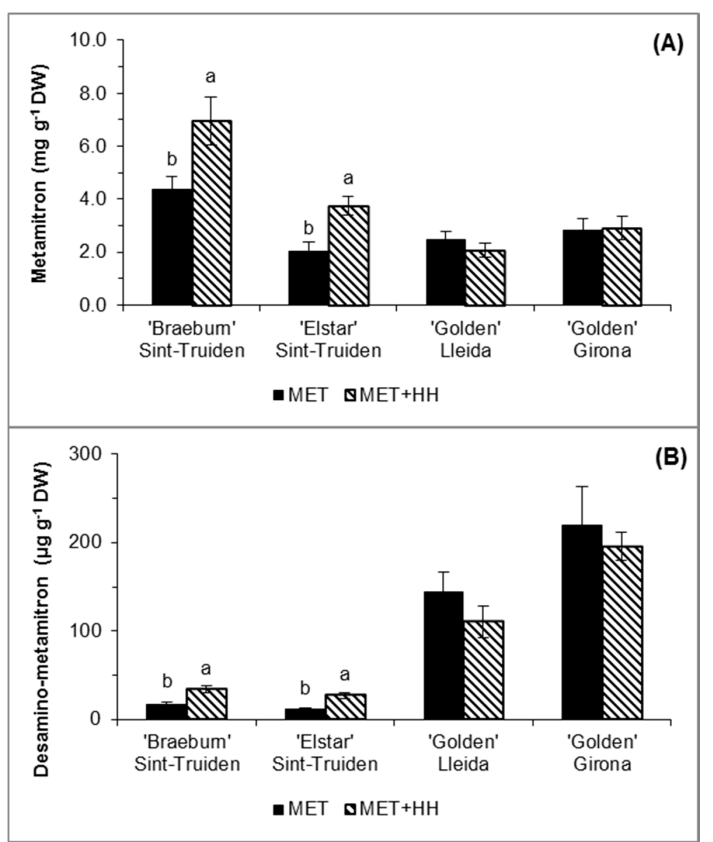

Figure 2. (A) Metamitron and (B) desamino-metamitron evaluated 2 days after spraying (DAS), in the trials with 'Braeburn' and 'Elstar' apples in Sint-Truiden, Belgium, and with 'Golden Reinders' apple in Girona and Lleida, Spain. For each parameter, the mean values \pm SE $(n=6)$ with different letters express significant differences between treatments within each cultivar/location using Tukey's HSD test $(\alpha$-value $\leq 0.05)$. No letters indicate no significant difference between means. 


\subsection{Leaf Net Photosynthesis}

The $\mathrm{HH}$ treatment did not affect the $\mathrm{P}_{\mathrm{n}}$ values of the cultivars 'Braeburn' and 'Elstar'; however, MET significantly decreased $P_{n}$ by $62 \%$ and $50 \%$ at 5 DAS and $33 \%$ and $35 \%$ at 7 DAS, in 'Braeburn' and 'Elstar', respectively, as compared to the CTR (Figure 3). The majority of the apparent MET recovery was related to a $\mathrm{P}_{\mathrm{n}}$ reduction in CTR and $\mathrm{HH}$ from 5 to 7 DAS, due to cloudy conditions.

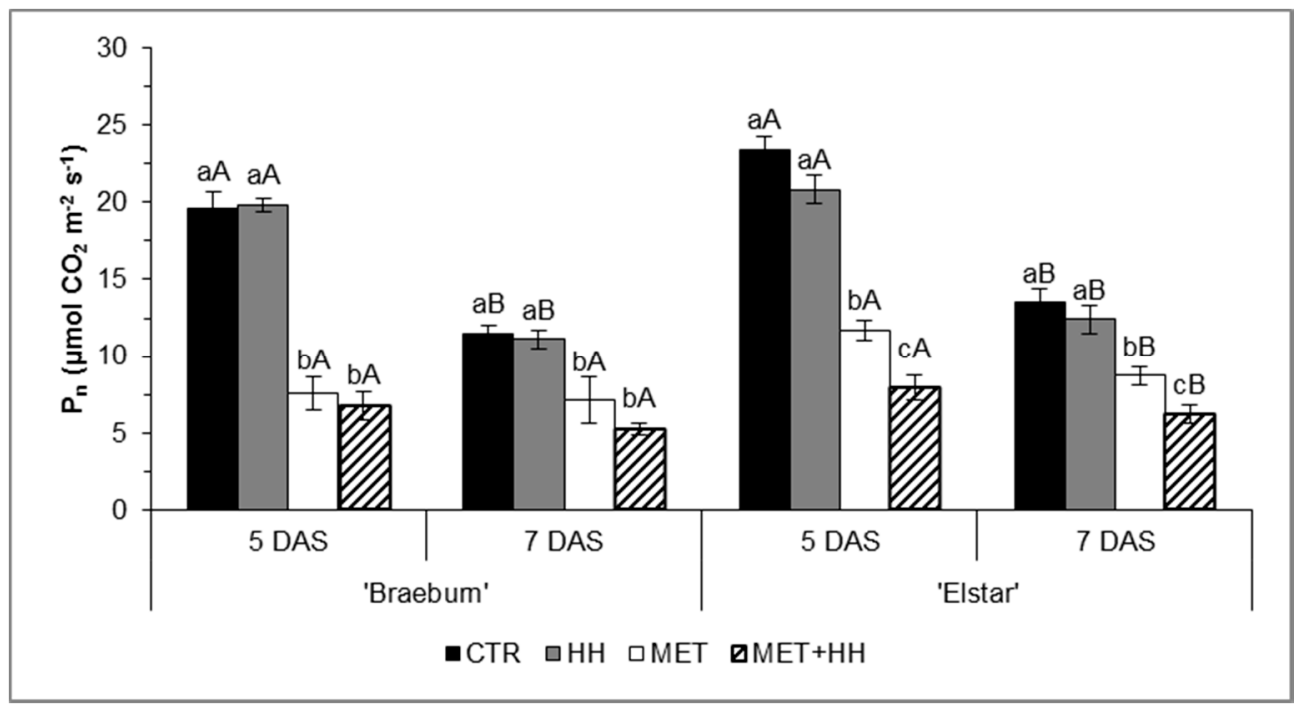

Figure 3. Leaf net photosynthesis $\left(\mathrm{P}_{\mathrm{n}}\right)\left(\mu \mathrm{mol} \mathrm{CO} \mathrm{C}^{-2} \mathrm{~s}^{-1}\right)$ evaluated 5 and 7 days after spraying (DAS), in the trials with 'Braeburn' and 'Elstar' apples in Sint-Truiden, Belgium. For each parameter, the mean values \pm SE $(n=8)$ followed by different letters express significant differences between treatments within each day $(\mathrm{a}, \mathrm{b}$, and $\mathrm{c})$, or between days within each treatment (A, B), using Tukey's HSD test $(\alpha$-value $\leq 0.05)$. Treatments were control (CTR), increased relative humidity for $3 \mathrm{~h}$ prior spraying $(\mathrm{HH})$, metamitron application at $247.5 \mathrm{mg} / \mathrm{L}(\mathrm{MET})$, and their combination (MET + HH).

Concerning MET $+\mathrm{HH}$, 'Braeburn' and 'Elstar' exhibited a tendency to a further $\mathrm{P}_{\mathrm{n}}$ decrease than compared with MET 5 and 7 DAS, although this was significant only for the latter.

\subsection{Leaf Soluble Sugars}

The HH treatment led to only a few modifications in the leaf soluble sugar content. The only variation registered was an increase in sorbitol in 'Braeburn', both at 5 and 7 DAS (Table 2). Metamitron (MET) significantly reduced the sucrose, fructose, sorbitol, and total sugar content at 5 and 7 DAS in 'Braeburn'. 'Elstar' showed similar trends, with significant reductions in sucrose (5 DAS), fructose (7 DAS), as well as of sorbitol, and the total sugars on both days (Table 2). In 'Golden Reinders' at Girona and Lleida, MET also reduced the sucrose content to one third and one fourth at 2 DAS, in Girona and Lleida, respectively, compared to the CTR (Table 3). At 5 DAS, these differences were somewhat reduced in Girona, whereas, in Lleida, the trees still presented a reduced content of sucrose of $50 \%$ compared to the CTR (Table 3). A similar reduction was observed in the sum of all analyzed sugars in Lleida and Girona (2 DAS) and in sorbitol and total sugars, in Lleida and Girona, respectively (5 DAS). However, the effect on these sugars was not as strong as with sucrose. In general, the lowest sugar contents were observed between 5 and 7 DAS. In contrast, the fructose content increased significantly in 'Golden Reinders' at Lleida and Girona at 2 and 5 DAS. 
Table 2. The sucrose, glucose, fructose, sorbitol, and total sugar concentration in the leaves ( $\mathrm{mg} \mathrm{g}^{-1}$ dry weight (DW)) evaluated 5 and 7 days after spraying (DAS) in trials with 'Braeburn' and 'Elstar' apples in Sint-Truiden, Belgium.

\begin{tabular}{|c|c|c|c|c|c|c|c|c|c|c|}
\hline \multirow{2}{*}{ Treatment $^{\mathrm{z}}$} & \multicolumn{10}{|c|}{5 DAS } \\
\hline & \multicolumn{2}{|c|}{ Sucrose } & \multicolumn{2}{|c|}{ Glucose } & \multicolumn{2}{|c|}{ Fructose } & \multicolumn{2}{|c|}{ Sorbitol } & \multicolumn{2}{|l|}{ Total } \\
\hline & & & & & ‘Braeburn' & & & & & \\
\hline CTR & $32.8 \pm 2.3$ & $\mathrm{aA}^{\mathrm{y}}$ & $28.7 \pm 2.4$ & NS & $3.2 \pm 0.5$ & $\mathrm{aA}$ & $85.7 \pm 5.4$ & $\mathrm{bB}$ & $150.6 \pm 10.1$ & $\mathrm{aA}$ \\
\hline HH & $32.0 \pm 1.6$ & $\mathrm{aA}$ & $31.9 \pm 1.8$ & & $3.1 \pm 0.3$ & $\mathrm{aA}$ & $98.4 \pm 3.5$ & $\mathrm{aB}$ & $166.2 \pm 6.7$ & $\mathrm{aA}$ \\
\hline MET & $23.4 \pm 2.2$ & $\mathrm{bA}$ & $28.2 \pm 0.9$ & & $2.3 \pm 0.4$ & $\mathrm{bA}$ & $75.8 \pm 5.2$ & $\mathrm{cB}$ & $131.7 \pm 7.6$ & $\mathrm{bA}$ \\
\hline $\mathbf{M E T}+\mathbf{H H}$ & $17.7 \pm 1.8$ & $\mathrm{cA}$ & $31.4 \pm 2.4$ & & $3.0 \pm 0.6$ & $\mathrm{aA}$ & $70.0 \pm 3.6$ & $\mathrm{cA}$ & $122.0 \pm 6.2$ & $\mathrm{bA}$ \\
\hline & & & & & 'Elstar' & & & & & \\
\hline CTR & $36.6 \pm 1.8$ & $\mathrm{aA}$ & $39.6 \pm 2.4$ & $\mathrm{aA}$ & $7.8 \pm 0.5$ & $\mathrm{aA}$ & $100.7 \pm 2.8$ & $\mathrm{aA}$ & $184.7 \pm 4.6$ & $\mathrm{aA}$ \\
\hline $\mathbf{H H}$ & $34.0 \pm 1.5$ & $\mathrm{aA}$ & $40.9 \pm 2.3$ & $\mathrm{aA}$ & $6.8 \pm 0.7$ & $\mathrm{aA}$ & $99.6 \pm 3.3$ & $\mathrm{aA}$ & $181.2 \pm 6.1$ & $\mathrm{aA}$ \\
\hline MET & $30.2 \pm 2.5$ & $\mathrm{bA}$ & $39.8 \pm 2.6$ & $\mathrm{aA}$ & $6.4 \pm 0.5$ & $\mathrm{aA}$ & $82.6 \pm 3.4$ & $\mathrm{bA}$ & $159.0 \pm 8.2$ & $\mathrm{bA}$ \\
\hline \multirow[t]{4}{*}{ MET + HH } & $22.6 \pm 1.2$ & $\mathrm{cA}$ & $39.4 \pm 1.9$ & $\mathrm{aA}$ & $3.4 \pm 0.5$ & $\mathrm{bA}$ & $82.2 \pm 3.6$ & $\mathrm{bA}$ & $147.6 \pm 4.8$ & $\mathrm{bA}$ \\
\hline & \multicolumn{10}{|c|}{7 DAS } \\
\hline & \multicolumn{2}{|c|}{ Sucrose } & \multicolumn{2}{|c|}{ Glucose } & \multicolumn{2}{|c|}{ Fructose } & \multicolumn{2}{|c|}{ Sorbitol } & \multicolumn{2}{|l|}{ Total } \\
\hline & & & & & ‘Braeburn' & & & & & \\
\hline CTR & $15.7 \pm 0.6$ & $\mathrm{abB}$ & $30.9 \pm 1.3$ & NS & $2.4 \pm 0.2$ & $\mathrm{aA}$ & $98.0 \pm 2.1$ & $\mathrm{bA}$ & $147.1 \pm 3.4$ & $\mathrm{bA}$ \\
\hline HH & $19.7 \pm 2.3$ & $\mathrm{aB}$ & $34.2 \pm 2.5$ & & $2.6 \pm 0.7$ & $\mathrm{aA}$ & $122.5 \pm 6.5$ & $\mathrm{aA}$ & $179.0 \pm 9.3$ & $\mathrm{aA}$ \\
\hline MET & $13.1 \pm 0.8$ & $\mathrm{bB}$ & $28.6 \pm 2.8$ & & $1.9 \pm 0.4$ & $\mathrm{bB}$ & $86.0 \pm 5.0$ & $\mathrm{cA}$ & $129.7 \pm 6.7$ & $\mathrm{cA}$ \\
\hline $\mathrm{MET}+\mathrm{HH}$ & $10.6 \pm 1.6$ & $\mathrm{bB}$ & $28.0 \pm 3.5$ & & $1.6 \pm 0.4$ & $\mathrm{bB}$ & $77.3 \pm 7.3$ & $\mathrm{cA}$ & $117.5 \pm 11.8$ & $\mathrm{cA}$ \\
\hline & & & & & 'Elstar' & & & & & \\
\hline CTR & $29.4 \pm 4.1$ & $\mathrm{aA}$ & $39.4 \pm 2.4$ & $\mathrm{aA}$ & $9.3 \pm 1.9$ & $\mathrm{aA}$ & $102.6 \pm 3.2$ & $\mathrm{aA}$ & $191.0 \pm 4.9$ & $\mathrm{aA}$ \\
\hline $\mathrm{HH}$ & $31.0 \pm 1.2$ & $\mathrm{aA}$ & $38.3 \pm 2.2$ & $\mathrm{aA}$ & $6.1 \pm 0.4$ & $a b A$ & $98.4 \pm 3.7$ & $\mathrm{aA}$ & $173.9 \pm 7.0$ & $\mathrm{bA}$ \\
\hline MET & $25.9 \pm 1.1$ & $\mathrm{aA}$ & $34.1 \pm 0.8$ & $\mathrm{aA}$ & $5.2 \pm 0.5$ & $\mathrm{bA}$ & $88.3 \pm 4.0$ & $\mathrm{bA}$ & $153.5 \pm 5.2$ & $\mathrm{cA}$ \\
\hline MET + HH & $16.5 \pm 2.9$ & $\mathrm{bB}$ & $26.7 \pm 4.1$ & $\mathrm{bB}$ & $4.1 \pm 0.6$ & $\mathrm{bA}$ & $64.9 \pm 10.2$ & $\mathrm{cB}$ & $112.3 \pm 17.6$ & $\mathrm{~dB}$ \\
\hline
\end{tabular}

${ }^{\mathrm{z}}$ Treatments were control (CTR), increased relative humidity for $3 \mathrm{~h}$ prior spraying $(\mathrm{HH})$, metamitron applied at $247.5 \mathrm{mg} / \mathrm{L}(\mathrm{MET})$, and their combination (MET + HH). ${ }^{\text {y }}$ For each parameter, the mean values $\pm \mathrm{SE}(n=6)$ followed by different letters indicate significant differences between treatments within each day $(a, b$, and $c)$, or between days within each treatment (A, B), using Tukey's HSD test at $\alpha \leq 0.05$. NS indicates no significant difference among values.

Table 3. The sucrose, glucose, fructose, sorbitol, and total sugar concentration in the leaf ( $\left.\mathrm{mg} \mathrm{g}^{-1} \mathrm{DW}\right)$ evaluated 2, 5, and 10 days after spraying (DAS) in the trials with 'Golden Reinders' apple in Lleida and Girona, Spain.

\begin{tabular}{|c|c|c|c|c|c|c|c|c|c|c|}
\hline \multirow{2}{*}{ Treatment ${ }^{\mathrm{z}}$} & \multicolumn{10}{|c|}{2 DAS } \\
\hline & \multicolumn{2}{|c|}{ Sucrose } & \multicolumn{2}{|c|}{ Glucose } & \multicolumn{2}{|c|}{ Fructose } & \multicolumn{2}{|c|}{ Sorbitol } & \multicolumn{2}{|c|}{ Total } \\
\hline & & & & & Leida & & & & & \\
\hline CTR & $19.0 \pm 1.3$ & $\mathrm{aB}^{\mathrm{y}}$ & $27.5 \pm 1.2$ & $\mathrm{aA}$ & $7.2 \pm 0.5$ & $\mathrm{bA}$ & $62.1 \pm 3.7$ & $\mathrm{aB}$ & $122.3 \pm 2.5$ & $\mathrm{aA}$ \\
\hline HH & $21.5 \pm 1.4$ & $\mathrm{aB}$ & $26.6 \pm 1.4$ & $\mathrm{aA}$ & $8.0 \pm 0.7$ & $\mathrm{bA}$ & $66.2 \pm 2.3$ & $\mathrm{aB}$ & $115.8 \pm 3.9$ & abA \\
\hline MET & $14.8 \pm 1.6$ & $\mathrm{bA}$ & $25.2 \pm 1.4$ & $\mathrm{aA}$ & $9.8 \pm 1.0$ & $\mathrm{aA}$ & $56.3 \pm 3.6$ & $\mathrm{aB}$ & $106.1 \pm 3.7$ & $\mathrm{bB}$ \\
\hline MET+HH & $15.2 \pm 2.6$ & $\mathrm{bA}$ & $25.0 \pm 1.3$ & $\mathrm{aA}$ & $8.7 \pm 0.8$ & $\mathrm{abA}$ & $60.4 \pm 3.1$ & $\mathrm{aB}$ & $110.5 \pm 2.6$ & $\mathrm{bB}$ \\
\hline CTR & $16.6 \pm 0.9$ & $\mathrm{aA}$ & $21.7 \pm 1.0$ & $\mathrm{aA}$ & $\begin{array}{c}\text { Girona } \\
7.2 \pm 0.4\end{array}$ & $\mathrm{bA}$ & $53.8+2.0$ & NS & $99.3+2.1$ & $\mathrm{aA}$ \\
\hline HH & $13.7 \pm 1.0$ & $\mathrm{aA}$ & $20.6 \pm 1.2$ & $\mathrm{aA}$ & $7.2 \pm 0.4$ & $\mathrm{bA}$ & $60.0 \pm 2.7$ & & $101.6 \pm 2.5$ & $\mathrm{aA}$ \\
\hline MET & $9.7 \pm 0.7$ & $\mathrm{bA}$ & $19.7 \pm 0.7$ & $\mathrm{aA}$ & $9.2 \pm 0.6$ & $\mathrm{aA}$ & $55.1 \pm 1.2$ & & $93.8 \pm 1.7$ & $\mathrm{bA}$ \\
\hline \multirow{3}{*}{ MET+HH } & $10.0 \pm 1.0$ & $\mathrm{bA}$ & $18.1 \pm 0.8$ & $\mathrm{aA}$ & $10.3 \pm 1.0$ & $\mathrm{aA}$ & $60.9 \pm 1.8$ & & $99.2 \pm 2.0$ & $\mathrm{aA}$ \\
\hline & \multicolumn{10}{|c|}{5 DAS } \\
\hline & \multicolumn{2}{|c|}{ Sucrose } & \multicolumn{2}{|c|}{ Glucose } & \multicolumn{2}{|c|}{ Fructose } & \multicolumn{2}{|c|}{ Sorbitol } & \multicolumn{2}{|c|}{ Total } \\
\hline & & & & & Leida & & & & & \\
\hline CTR & $29.3 \pm 1.9$ & $\mathrm{aA}$ & $21.8 \pm 0.5$ & $a b B$ & $6.2 \pm 0.6$ & $\mathrm{bA}$ & $76.3 \pm 3.2$ & $\mathrm{aA}$ & $129.7 \pm 5.8$ & $\mathrm{aA}$ \\
\hline HH & $31.7 \pm 2.2$ & $\mathrm{aA}$ & $23.8 \pm 0.9$ & $\mathrm{aA}$ & $5.9 \pm 0.2$ & $\mathrm{bB}$ & $75.2 \pm 3.7$ & $\mathrm{aA}$ & $133.2 \pm 5.8$ & $\mathrm{aA}$ \\
\hline MET & $16.5 \pm 2.5$ & $\mathrm{bA}$ & $19.3 \pm 0.9$ & $\mathrm{bB}$ & $9.6 \pm 1.2$ & $\mathrm{aA}$ & $68.2 \pm 6.6$ & $\mathrm{bA}$ & $120.7 \pm 4.7$ & $\mathrm{abA}$ \\
\hline MET+HH & $15.3 \pm 1.8$ & $\mathrm{bA}$ & $19.2 \pm 0.7$ & $\mathrm{bB}$ & $8.7 \pm 0.8$ & $\mathrm{aA}$ & $62.6 \pm 3.6$ & $\mathrm{bB}$ & $105.8 \pm 4.5$ & $\mathrm{bB}$ \\
\hline CTR & $13.4 \pm 0.9$ & $\mathrm{aA}$ & $24.3 \pm 0.6$ & $\mathrm{aA}$ & $\begin{array}{c}\text { Girona } \\
7.2 \pm 0.4\end{array}$ & $\mathrm{bA}$ & $58.6 \pm 1.9$ & NS & $103.7 \pm 2.5$ & $\mathrm{aA}$ \\
\hline $\mathrm{HH}$ & $13.5 \pm 0.6$ & $\mathrm{aA}$ & $21.6 \pm 0.7$ & $\mathrm{abA}$ & $5.9 \pm 0.4$ & $\mathrm{bA}$ & $55.3 \pm 2.0$ & & $96.3 \pm 1.9$ & $\mathrm{abA}$ \\
\hline MET & $8.8 \pm 1.0$ & $\mathrm{bA}$ & $19.8 \pm 1.0$ & $\mathrm{bA}$ & $8.4 \pm 0.7$ & $\mathrm{aA}$ & $56.7 \pm 2.7$ & & $93.6 \pm 3.2$ & $\mathrm{bA}$ \\
\hline MET+HH & $9.4 \pm 0.8$ & $\mathrm{bA}$ & $19.5 \pm 0.9$ & $\mathrm{bA}$ & $7.1 \pm 0.8$ & $\mathrm{bB}$ & $54.4 \pm 2.5$ & & $88.7 \pm 1.9$ & $\mathrm{bB}$ \\
\hline
\end{tabular}


Table 3. Cont

\begin{tabular}{|c|c|c|c|c|c|c|c|c|c|c|}
\hline \multirow[b]{3}{*}{ CTR } & \multicolumn{10}{|c|}{10 DAS } \\
\hline & \multicolumn{2}{|c|}{ Sucrose } & \multicolumn{2}{|c|}{ Glucose } & \multicolumn{2}{|c|}{ Fructose } & \multicolumn{2}{|c|}{ Sorbitol } & \multicolumn{2}{|c|}{ Total } \\
\hline & $16.8 \pm 0.7$ & $\mathrm{aB}$ & $23.0 \pm 1.1$ & $\mathrm{aB}$ & $6.6 \pm 0.6$ & $\mathrm{aA}$ & $80.7 \pm 2.9$ & $\mathrm{aA}$ & $126.0 \pm 2.0$ & $\mathrm{aA}$ \\
\hline $\mathrm{HH}$ & $17.5 \pm 0.8$ & $\mathrm{aB}$ & $24.0 \pm 0.9$ & $\mathrm{aA}$ & $7.3 \pm 0.4$ & $\mathrm{aA}$ & $81.1 \pm 3.2$ & $\mathrm{aA}$ & $132.0 \pm 2.7$ & $\mathrm{aA}$ \\
\hline MET & $15.8 \pm 0.8$ & $\mathrm{aA}$ & $24.3 \pm 1.0$ & $\mathrm{aA}$ & $7.5 \pm 0.5$ & $\mathrm{aB}$ & $76.6 \pm 2.8$ & $\mathrm{aA}$ & $124.1 \pm 3.0$ & $\mathrm{aA}$ \\
\hline MET+HH & $16.8 \pm 0.9$ & $\mathrm{aA}$ & $24.2 \pm 0.9$ & $\mathrm{aA}$ & $6.8 \pm 0.5$ & $\mathrm{aB}$ & $78.6 \pm 3.1$ & $\mathrm{aA}$ & $126.3 \pm 3.0$ & $\mathrm{aA}$ \\
\hline
\end{tabular}

$\mathrm{z}$ Treatments were Control (CTR), increased relative humidity for $3 \mathrm{~h}$ prior spraying $(\mathrm{HH})$, metamitron applied at $247.5 \mathrm{mg} / \mathrm{L}(\mathrm{MET})$, and their combination $(\mathrm{MET}+\mathrm{HH}) .{ }^{\text {y }}$ For each parameter, the mean values $\pm \mathrm{SE}(n=6)$ followed by different letters indicate significant differences between treatments within each day ( $a$ and b), or between days within each treatment (A, B), using Tukey's HSD test at $\alpha \leq 0.05$. NS indicates no significant difference among values.

The combined exposure to metamitron and high relative humidity conditions (MET+HH) significantly exacerbated the MET impact on sucrose reduction in both cvs. at 5 DAS and on 'Elstar' at 7 DAS (Table 2). Sucrose content was significantly lower in 'Braeburn' (31\%) and 'Elstar' (26\%) than under MET. For many other sugars, values observed in the MET + HH treatment did not always differ from the MET alone treatment (Tables 2 and 3). Additionally, at 7 DAS, 'Elstar' presented significantly lower values for all sugars except fructose under MET+HH conditions when compared with MET. Notably, in Lleida, differences observed among the four treatments until 5 DAS were no longer present at 10 DAS for all of the sugars.

\subsection{Shoot Growth and Yield Parameters}

The increase of relative humidity $(\mathrm{HH})$ did not alter the daily shoot growth rate; however, both MET and MET $+\mathrm{HH}$ treatments induced significant increases of $40 \%$ in 'Golden Reinders' at Lleida (both treatments), and 120\% in MET, and 96\% in MET+HH in Girona compared to the CTR (Figure 4).

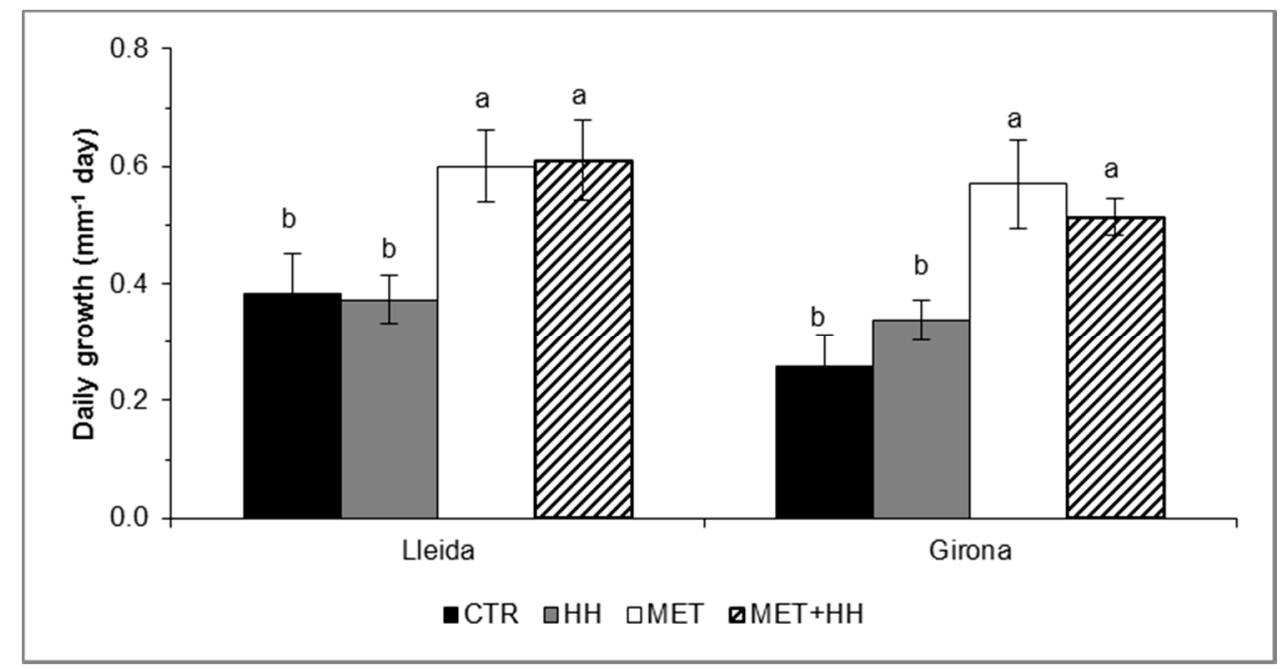

Figure 4. The daily shoot growth rate $\left(\mathrm{mm}^{-1}\right.$ day) evaluated 10 days after spraying (DAS), in the trials with 'Golden Reinders' apple at Lleida and Girona, Spain. Mean values \pm SE $(n=32)$ followed by different letters express significant differences between treatments within each day using Tukey's HSD test $(\alpha \leq 0.05)$. Control (CTR), increased relative humidity for $3 \mathrm{~h}$ prior spraying $(\mathrm{HH})$, metamitron $247.5 \mathrm{mg} / \mathrm{L}(\mathrm{MET})$, and their combination $(\mathrm{MET}+\mathrm{HH})$.

The HH conditions did not significantly affect the yield parameters, regardless of the year and cultivar (Table 4). In contrast, MET significantly decreased the number of fruits and the yield and, consequently, improved the fruit quality in all the parameters analyzed in Sint-Truiden in 'Braeburn' and 'Elstar', while in Girona and Lleida, in 'Golden Reinders', the same tendency was observed although not significantly (except for an increase in the percentage of fruits in the fruit size class $>70 \mathrm{~mm}$, in Girona). MET strongly reduced the number of fruits per 100 flower clusters, $60 \%$ and $51 \%$, in 'Braeburn' and 
'Elstar', respectively, with a consequent improvement in the percentage of fruits larger than $70 \mathrm{~mm}$ of $20 \%$ in both cultivars.

Table 4. The number of fruits per 100 flower clusters, fruit weight $(\mathrm{g})$, yield per tree $(\mathrm{kg})$, and fruits in the fruit size class $>70 \mathrm{~mm}(\%)$ at harvest, in trials with 'Braeburn' and 'Elstar' apples performed in Sint-Truiden, Belgium, and with 'Golden Reinders' in Lleida and Girona, Spain.

\begin{tabular}{|c|c|c|c|c|c|c|c|c|c|c|}
\hline \multirow[t]{2}{*}{ Location } & \multirow[t]{2}{*}{$\begin{array}{c}\text { Cultivar } \\
\text { Year }\end{array}$} & \multirow{2}{*}{$\begin{array}{l}\text { Treatment }^{z} \\
\text { CTR }\end{array}$} & \multicolumn{2}{|c|}{$\begin{array}{c}\text { Fruits/100 } \\
\text { Flower Clusters }\end{array}$} & \multicolumn{2}{|c|}{ Fruit Weight (g) } & \multicolumn{2}{|c|}{$\begin{array}{l}\text { Yield/Tree } \\
\text { (kg) }\end{array}$} & \multicolumn{2}{|c|}{$\begin{array}{l}\% \text { Fruits } \\
>70 \mathrm{~mm}\end{array}$} \\
\hline & & & $62.0 \pm 5.4$ & $a^{y}$ & $166.0 \pm 4.4$ & $\mathrm{~b}$ & $14.7 \pm 0.9$ & a & $75.9 \pm 3.3$ & $\mathrm{~b}$ \\
\hline \multirow{7}{*}{ Sint-Truiden } & 'Braeburn' & $\mathrm{HH}$ & $58.0 \pm 5.5$ & a & $170.1 \pm 4.5$ & b & $14.4 \pm 1.3$ & a & $79.9 \pm 4.6$ & $\mathrm{~b}$ \\
\hline & 2018 & MET & $27.1 \pm 5.7$ & $\mathrm{~b}$ & $214.8 \pm 7.8$ & a & $7.4 \pm 0.9$ & $\mathrm{~b}$ & $94.4 \pm 4.6$ & a \\
\hline & & $\mathrm{MET}+\mathrm{HH}$ & $20.6 \pm 4.4$ & $\mathrm{~b}$ & $241.8 \pm 5.4$ & a & $7.8 \pm 1.3$ & $\mathrm{~b}$ & $98.9 \pm 1.1$ & a \\
\hline & & CTR & $104.3 \pm 12.2$ & $\mathrm{a}$ & $121.0 \pm 6.5$ & $\mathrm{~b}$ & $9.8 \pm 0.6$ & a & $67.9 \pm 9.1$ & $\mathrm{~b}$ \\
\hline & 'Elstar' & $\mathrm{HH}$ & $101.0 \pm 14.2$ & a & $125.3 \pm 6.7$ & $\mathrm{~b}$ & $8.8 \pm 1.2$ & a & $60.3 \pm 5.4$ & $\mathrm{~b}$ \\
\hline & 2018 & MET & $62.4 \pm 12.3$ & $\mathrm{ab}$ & $151.0 \pm 5.1$ & a & $6.9 \pm 1.0$ & $a b$ & $83.9 \pm 2.6$ & $\mathrm{a}$ \\
\hline & & $\mathrm{MET}+\mathrm{HH}$ & $42.5 \pm 4.2$ & $\mathrm{~b}$ & $157.1 \pm 4.5$ & a & $4.7 \pm 0.6$ & $\mathrm{~b}$ & $87.7 \pm 3.0$ & a \\
\hline \multirow{4}{*}{ Girona } & \multirow{4}{*}{$\begin{array}{l}\text { 'Golden } \\
\text { Reinders' } \\
2019\end{array}$} & CTR & $141.6 \pm 8.5$ & NS & $126.7 \pm 5.0$ & NS & $48.2 \pm 3.5$ & NS & $22.6 \pm 6.3$ & $\mathrm{~b}$ \\
\hline & & $\mathrm{HH}$ & $143.2 \pm 7.9$ & & $129.4 \pm 4.8$ & & $41.1 \pm 4.1$ & & $28.4 \pm 4.5$ & $b$ \\
\hline & & MET & $126.7 \pm 9.0$ & & $141.6 \pm 8.5$ & & $38.1 \pm 4.0$ & & $43.0 \pm 2.6$ & $\mathrm{a}$ \\
\hline & & $\mathrm{MET}+\mathrm{HH}$ & $129.4 \pm 4.8$ & & $143.2 \pm 2.9$ & & $34.7 \pm 2.6$ & & $42.6 \pm 3.4$ & a \\
\hline \multirow{4}{*}{ Lleida } & \multirow{4}{*}{$\begin{array}{l}\text { 'Golden } \\
\text { Reinders' } \\
2019\end{array}$} & CTR & $137.8 \pm 6.9$ & NS & $113.1 \pm 4.7$ & NS & $45.1 \pm 3.5$ & NS & $44.1 \pm 7.3$ & NS \\
\hline & & $\mathrm{HH}$ & $127.0 \pm 9.5$ & & $118.8 \pm 3.2$ & & $45.2 \pm 4.1$ & & $46.2 \pm 3.4$ & \\
\hline & & MET & $106.4 \pm 6.2$ & & $129.4 \pm 2.8$ & & $39.1 \pm 0.8$ & & $61.3 \pm 2.0$ & \\
\hline & & $\mathrm{MET}+\mathrm{HH}$ & $104.0 \pm 14.6$ & & $127.6 \pm 4.9$ & & $38.1 \pm 3.3$ & & $58.3 \pm 4.0$ & \\
\hline
\end{tabular}

$\mathrm{z}$ Treatments were Control (CTR), increased relative humidity for $3 \mathrm{~h}$ prior spraying (HH), metamitron applied at $247.5 \mathrm{mg} / \mathrm{L}(\mathrm{MET})$, and their combination $(\mathrm{MET}+\mathrm{HH}) .{ }^{\text {y }}$ For each parameter, the mean values $\pm \mathrm{SE}(n=8)$ followed by different letters indicate significant differences between treatments using Tukey's HSD test at $\alpha \leq 0.05$. NS indicates no significant difference among values.

In 'Golden Reinders', the tree response to metamitron was lower, resulting in smaller reductions in the number of fruits per 100 flower clusters, ranging between $10 \%$ to $20 \%$ in both locations. The outcome in the fruit size was significant, resulting in 39\% and $25 \%$ more fruits larger than $70 \mathrm{~mm}$, in Girona and Lleida, respectively. In Sint-Truiden, MET $+\mathrm{HH}$ promoted an even greater reduction of the fruit yield per tree and a greater fruit quality improvement. The latter contributed a further decrease in the number of fruits per 100 flower clusters of 31\% and 47\% in 'Braeburn' and 'Elstar', respectively, compared with MET alone. Consequently, a strong yield reduction and quality increment was observed in the other parameters. In the trials conducted in Lleida and Girona, there were no differences observed between MET applied alone and the combined exposure (MET+HH). Although the variation patterns were quite similar to those found in Sint-Truiden, in most cases, there were no significant differences between all treatments and their respective CTR.

\section{Discussion}

\subsection{Metamitron Absorption}

There are many factors affecting leaf chemical uptake dynamics, with relative humidity being one of them [17-20]. High relative humidity conditions can affect the leaf morphological structure, reducing the thickness of the parenchyma and both the adaxial and abaxial epidermis [30,31], leaving a softer and thinner (less waxy and more permeable) cuticle, which is more prone to chemical absorption. Previous observations [20] confirmed these aspects as a 50\% increase of urea leaf absorption was observed after a relative humidity increase from $35 \%$ to $50 \%$. In addition, the relative humidity influences the number of stomata in the leaf and its state, and drier conditions result in an increase in the stomatal number and closure [23,30].

High relative humidity conditions allow a liquid layer to remain on the leaf surface, promoting a chemical in solution to be absorbed over a longer period of time by increasing the drying period [32]. This was verified by Orbovic et al. [20] who observed the longer persistence of a wet layer of urea solution for $24 \mathrm{~h}$ on grapefruit leaves when the relative humidity levels were $80-100 \%$. Leaves 
developed under more humid and cold climates, such as Sint-Truiden, Belgium, by comparison with Lleida and Girona, Spain, may have different morpho-structural characteristics, such as those described above, which allow for a greater absorption, justifying the increase of absorption in this location.

These characteristics may also explain the higher concentration of metamitron in leaves from the combined treatment (MET $+\mathrm{HH})$ observed in both cultivars in Sint-Truiden, but not in Lleida and Girona. The temperature increase that occurred only in Sint-Truiden (Figure 1) may have also influenced absorption. An increase in urea absorption was previously verified when the temperature was $28^{\circ} \mathrm{C}$ compared to $19^{\circ} \mathrm{C}$ [20]. In Sint-Truiden ('Braeburn' and 'Elstar'), an increase in temperature occurred during the $\mathrm{HH}$ period, from 16 to $23^{\circ} \mathrm{C}$, which may additionally explain the contrast of no extra absorption caused by $\mathrm{HH}$ at Lleida and Girona. This may also be related to 'Golden Reinders' leaf characteristics, which may be less susceptible to morphological changes under different relative humidity conditions, producing more metamitron degradation.

\subsection{Leaf Net Photosynthesis}

Metamitron significantly reduced the $P_{n}$ by $50-60 \%$ (5 DAS); a greater reduction than the $19 \%$ decrease observed by Gabardo et al. [33] using 'Golden Delicious' apple with a similar $247.5 \mathrm{mg} / \mathrm{L}$ application, or compared with the $30 \%$ reduction by 3 DAS of a $350 \mathrm{mg} / \mathrm{L}$ dose in 'Fuji Suprema' apple trees [34]. In the latter study, a full $P_{n}$ recovery was observed by 7 DAS, whereas our data by that time still showed $P_{n}$ values one third lower in MET than in the CTR. The combined treatment $(\mathrm{MET}+\mathrm{HH})$ resulted in a tendency for lower $\mathrm{P}_{\mathrm{n}}$ rates in 'Braeburn' and significantly lower $\mathrm{P}_{\mathrm{n}}$ in 'Elstar' at 5 and 7 DAS, which is in line with the greater absorption of metamitron in the MET+HH treatment (evaluated at 2 DAS) (Figure 2) as compared with the single MET application in these cultivars.

\subsection{Leaf Soluble Sugars}

Photosynthesis is active primarily in mature leaf mesophyll cells, and sucrose-the primary photosynthate-is transported to meristems and sink organs. Sugar sensing and signalling are involved in the control of growth and development during the entire plant cycle, ensuring the optimal use of carbon and an appropriate response of the metabolism to specific situations, such as the carbohydrate shortage caused by photoinhibiting thinners and, at the limit, triggering fruit abscission $[13,18]$.

The strong $P_{n}$ reduction after metamitron application would have limited the photoassimilate production in accordance with the lower sucrose and sorbitol content found for the MET and MET $+\mathrm{HH}$ treatments, especially at 5 DAS (Tables 2 and 3). By interrupting the thylakoid electron transfer [3], metamitron impairs ATP and $\mathrm{NADPH}_{2}$ and, therefore, $\mathrm{CO}_{2}$ fixation. In this case, a shortage in the soluble sugar production can be expected, as reported by [35] after applying 75, 150, and $300 \mathrm{mg} / \mathrm{L}$ metamitron in mandarin. A reduction in the total sugars was found at 1 DAS, which persisted until 7 DAS with the $300 \mathrm{mg} / \mathrm{L}$ application, leading to a $25 \%$ reduction in the number of fruits. In our study, we saw the strongest reduction in sucrose and sorbitol, at 5 days after a single application of MET, resulting in a sucrose decrease of $27 \%, 28 \%$ and $44 \%$, in 'Braeburn', 'Elstar', and 'Golden Reinders' and a sorbitol decrease of $12 \%$ and $18 \%$ in 'Braeburn' and 'Elstar'.

In the cultivars 'Braeburn' and 'Elstar', the minimum values of sucrose and sorbitol were observed between 5 and 7 DAS after application of MET prior to a $3 \mathrm{~h}$ period of high relative humidity (MET+HH). This treatment, resulted in 25\% less sucrose content than MET alone in both cultivars, at 5 DAS, and $36 \%$ less sucrose content than MET on 'Elstar', at 7 DAS. The differences between the content of sorbitol in MET and MET+HH were only significant in 'Elstar' at 7DAS, with the latter treatment showing $27 \%$ sorbitol than MET alone. These results in sugar shortage are in line with the absorption increase and consequent stronger $\mathrm{P}_{\mathrm{n}}$ inhibition in MET $+\mathrm{HH}$.

\subsection{Shoot Growth and Thinning Efficacy}

In the early phase of fruit development, there exists a strong sink competition for carbohydrates between the vegetative parts of the tree (shoots) and the small fruitlets. Under a situation of strong 
vegetative growth, a negative carbohydrate balance and induced fruit abscission is more likely [11]. Under limited sugar availability, during the first 40 DAFB, shoot growth has priority over fruit growth for carbohydrate partitioning [1,11,12]; therefore, this response has a cost, and may contribute to a negative $\mathrm{CH}$ balance that can enhance fruit abscission.

In the present study, the shoot growth increased after metamitron application, that is, in a soluble sugar limiting context, confirmed by the general sucrose and sorbitol reduction (Tables 2 and 3), although starch remobilization from the tree structures into soluble sugars might have compensated in some extent for the decline of photosynthate production [36-38].

The shoot growth could be interpreted as a tree response to MET application by producing more fully-functioning leaves capable of restoring the tree photosynthetic capacity, which would have aggravated the competition with the developing fruits, and contributed to the reduction of the number of fruits per 100 flower clusters in all cultivars in the MET treatment. This was stronger in 'Braeburn' and 'Elstar', which was likely linked to higher metamitron absorption (Figure 2). This greater effect on fruit numbers in these cultivars promoted a significant improvement in the fruit quality (fruit weight and percentage of fruits in the fruit size class $>70 \mathrm{~mm}$ ) while reducing the global yield per tree to about half and $2 / 3$, respectively.

These findings were in line with those reporting a decrease in the number of fruits per tree to about half, and a rise in the average fruit weight and size, accompanied with a 2/3 reduction in yield in the cultivar 'Fred Hough' apple after spraying with $384 \mathrm{mg} / \mathrm{L}$ metamitron [39], and with a $11 \%$ and $39 \%$ decrease in 'Golden Reinders' after a $247.5 \mathrm{mg} / \mathrm{L}$ application at $12 \mathrm{~mm}$ [33], in both cases with a reduction in yield.

When the metamitron application was performed after a $3 \mathrm{~h}$ exposure to high relative humidity conditions $(\mathrm{MET}+\mathrm{HH})$ in the present study, the cultivars responded in a different way. In 'Braeburn' and 'Elstar', this treatment promoted $24 \%$ and $32 \%$ less fruit per 100 flower clusters with consequent improvements in the fruit weight and fruit size, whereas in 'Golden Reinders', there was no extra thinning response compared to MET sprayed under environmental conditions. As described in Section 4.1 above, leaf morphology varies from cultivar to cultivar, resulting in certain cultivars that are more susceptible to increased absorption under high relative humidity than others. In addition, 'Braeburn' and 'Elstar' were also exposed to $1 \mathrm{~h}$ of high relative humidity after spraying (average 18.4\%, although half of the $3 \mathrm{~h}$ average in Girona, $35 \%)$ and higher temperatures $\left(7^{\circ} \mathrm{C}\right)$, which might indicate that temperature and relative humidity after spraying have a greater effect on the metamitron efficacy.

The genetic factors, which determine the cultivars that are more prone to thinning, are also expressed as a cultivar susceptibility. 'Braeburn' is classified as an easy cultivar to thin, and 'Golden Reinders' is considered more difficult to obtain a thinning response [16], which is in line with our results. In brief, the thinning efficacy is a result of many environmental and orchard factors that interact with each other. A tree's age influences the vigour and tree carbohydrate reserves, which can make the difference between a strong thinning efficacy and resistance in response to the application of a thinner. The 'Braeburn' and 'Elstar' trees were 4 years old, consequently with less reserves and less vigour and were likely more susceptible to thinning. On the other side, the 'Golden Reinders' trees were 16 years old, with a larger trunk diameter, meaning that many carbohydrate reserves were stored, positively influencing the carbohydrate balance and, hence, increasing the resilience to environmental changes, such as high relative humidity. Such trees were apparently less sensitive to metamitron, which affects the thinning response.

\section{Conclusions}

Environmental conditions change from region to region, which can be translated as different leaf morphological and structural characteristics with different absorption capacities. In Sint-Truiden particularly with 'Braeburn' apple, there was more absorption than in Girona and Lleida under ambient relative humidity, likely due to a higher relative humidity during leaf development. Absorption was 
enhanced by short-term high relative humidity conditions. This resulted in greater $\mathrm{P}_{\mathrm{n}}$ inhibition and a strong reduction in the leaf soluble sugar content, primarily for sucrose and sorbitol.

This reduction, together with the tree age, resulted in a large fruit abscission in MET and MET $+\mathrm{HH}$, the latter with a tendency for lower numbers of fruit, a higher fruit weight, size improvements, and with a stronger yield reduction compared with MET alone, an over thinning response. Although with similar tendencies and together with the permanence of shoot growth, less metamitron absorption (and higher degradation) in 'Golden Reinders', along with the older tree age, would explain the smaller impact on fruit thinning and yield reduction, fruit weight, and \% of fruits over $70 \mathrm{~mm}$.

This study indicated that relative humidity for at least $3 \mathrm{~h}$ prior to metamitron application may enhance metamitron thinning efficacy under specific circumstances, such as greater humidity and colder temperatures that leave a tree more susceptible to thinning and including the cultivar susceptibility and tree age. In addition, this raises the question of how temperature, in combination with high relative humidity (either before or after spraying), can affect the thinning results, which should be further explored.

Author Contributions: Conceptualization, W.V., J.B., and L.A.; data curation, G.À. and J.C.; funding acquisition, J.C.R., L.A., and C.M.O.; investigation, G.À. and J.C.; methodology, W.V., L.A., and C.M.O.; project administration, C.M.O.; resources, C.M.O. and N.R.; supervision, J.C.R., L.A. and C.M.O.; validation, W.V., and C.M.O.; writing - review and editing, J.C.R. and C.M.O. All authors have read and agreed to the published version of the manuscript.

Funding: This study was supported by ADAMA-Israel, as well as by Fundação para a Ciência e a Tecnologia (FCT) through the research units UID/AGR/04129/2020 (LEAF), UIDB/00239/2020 (CEF), and UIDP/04035/2020 (GeoBioTec).

Conflicts of Interest: The authors declare no conflict of interest.

\section{References}

1. Lakso, A.N.; Robinson, T.L.; Goffinet, M.C.; White, M.D. Apple Fruit Growth Responses to Varying Thinning Methods and Timing. Acta Hortic. 2001, 557, 407-412. [CrossRef]

2. Robinson, T.L.; Lakso, A.N. Between Year and Within Year Variation in Chemical Fruit Thinning Efficacy of Apple During Cool Springs. Acta Hortic. 2004, 636, 283-294. [CrossRef]

3. Abbaspoor, M.; Teicher, H.B.; Streibig, J.C. The Effect of Root-Absorbed PSII Inhibitors on Kautsky Curve Parameters in Sugar Beet. Weed Res. 2006, 46, 226-235. [CrossRef]

4. Guidi, L.; Degl'innocenti, E. Imaging of Chlorophyll a Fluorescence: A Tool to Study Abiotic Stress in Plants. In Abiotic Stress in Plants-Mechanisms and Adaptations 2011; Shanker, A., Ed.; InTech: London, UK, 2011; ISBN 978-953-307-394-1. [CrossRef]

5. Maxwell, K.; Johnson, G.N. Chlorophyll Fluorescence-A Practical Guide. J. Exp. Bot. 2000, 51, 659-668. [CrossRef] [PubMed]

6. Byers, R.; Carbaugh, D.; Presley, C.; Wolf, T. The Influence of Low Light Levels on Apple Fruit Abscission. J. Hortic. Sci. 1991, 66, 1-17. [CrossRef]

7. Lakso, A.; Grapadelli, L.C. Implications of Pruning and Training Practices to Carbon Portioning and Fruit Development in Apple Fruit. J. Hortic. Sci. 1992, 70, 389-394. [CrossRef]

8. Zibordi, M.; Domingos, S.; Corelli Grappadelli, L. Thinning Apples Via Shading: An Appraisal Under Field Conditions. J. Hortic. Sci. Biotech. 2009, 84, 138-144. [CrossRef]

9. Elsysy, M.; Serra, S.; Schwallier, P.; Musacchi, S.; Einhorn, T. Net Enclosure of 'Honeycrisp' and 'Gala' Apple Trees at Different Bloom Stages Affects Fruit Set and Alters Seed Production. Agronomy 2019, 9, 478. [CrossRef]

10. Miller, S.; Hott, C.; Tworkoski, T. Shade Effects on Growth, Flowering and Fruit of Apple. J. Appl. Hortic. 2015, 17, 101-105. [CrossRef]

11. Forshey, G.; Elfving, D. The Relationship between Vegetative Growth and Fruiting in Apple Trees. In Horticultural Reviews; Janick, J., Ed.; Timber Press: Portland, OR, USA, 1989; Volume 11. [CrossRef]

12. Bepete, M.; Lakso, A. Differential Effects of Shade on Early-season Fruit and Shoot Growth Rates in 'Empire' Apple. HortScience 1998, 33, 823-825. [CrossRef] 
13. Jones, K.M.; Bound, S.A.; Oakford, M.J.; Gillard, P. Modeling Thinning of Pome Fruits. Plant Growth Regul. 2000, 31, 75-84. [CrossRef]

14. Doerflinger, F.; Lakso, A.; Braun, P. Adapting Malusim Apple Tree Model for the 'Gala' Cultivar. Proc. Ix ${ }^{\text {th }}$ IS on Modelling in Fruit Research and Orchard Management. Acta Hortic. 2015, 1068, 267-271. [CrossRef]

15. Rosa, N.; Verjans, W.; Oliveira, C.; Bylemans, D.; Remy, S. Comparison between 6-Benzyladenine and Metamitron as Thinning Agents in 'Royal Gala', 'Cripps Pink' and 'Red Delicious' Apple Cultivars. Proc. Proceedings of the EUFRIN Thinning working Group Symposia. Acta Hortic. 2018, 1221, 52-58. [CrossRef]

16. Washington State University. Crop Protection Guide for Tree Fruits in Washington-Apple Chemical Thinning. Available online: http://cpg.treefruit.wsu.edu/bioregulator-sprays/apple-chemical-thinning/ (accessed on 4 August 2020).

17. Robinson, T.L.; Hoying, S.; Sazom, M.M.; Rufato, A. Precision Crop Load Management Part 2. N. Y. Fruit Q. 2013, 22, 9-13.

18. Lakso, A.; Robinson, T.L. Decision Support for Apple Thinning Based on Carbon Balance Modeling. Proc. IX ${ }^{\text {th }}$ IS on Modelling in Fruit Research and Orchard Management. Acta Hortic. 2015, 1068, 235-242. [CrossRef]

19. New England-Tree Fruit Management Guide. Available online: https://netreefruit.org/apples/plant-growthregulators/apple-fruit-thinning (accessed on 5 August 2020).

20. Orbovic, V.; Achor, D.; Petacek, P.; Syvertsen, J. Air Temperature, RELATIVE HUMIDITY, and Leaf Age Affect Penetration of Urea through Grapefruit Leaf Cuticles. J. Am. Hortic. Sci. 2001, 126, 44-50. [CrossRef]

21. Hernandez, M.; Montes, F.; Ruiz, F.; Lopez, G.; Pita, P. The Effect of Vapour Pressure Deficit on Stomatal Conductance, Sap pH and Leaf-specific Hydraulic Conductance in Eucalyptus Globulus Clones Grown Under Two Watering Regimes. Ann. Bot. 2016, 117, 1063-1071. [CrossRef]

22. Merilo, E.; Yarmolinsky, D.; Jalakas, P.; Parik, H.; Tulva, I.; Rasulov, B.; Kilk, K.; Kollist, H. Stomatal VPD Response: There is More to the Story Than ABA. Plant Physiol. 2018, 176, 851-864. [CrossRef]

23. Schulze, E.D.; Lange, O.L.; Buschbom, U.; Kappen, L.; Evenari, M. Stomatal Responses Changes in RELATIVE HUMIDITY in Plants Growing in the Desert. Planta 1972, 108, 259-270. [CrossRef]

24. Patin, F.; Blatt, M. Stomatal Response to RELATIVE HUMIDITY: Blurring the Boundary between Active and Passive Movement. Plant Physiol. 2018, 176, 485-488. [CrossRef]

25. Lafer, G. Effects Of Chemical Thinning With Metamitron on Fruit Set, Yield and Fruit Quality of 'Elstar'. Proceedings of $\mathrm{XI}^{\text {th }}$ International Symposium on Plant Bioregulators in Fruit Production. Acta Hortic. 2010, 884, 531-536. [CrossRef]

26. Robinson, T.L. Managing Fruit Abscission in Apple. XXIX IHC—Proc. Int. Symposia on Abscission Processes in Horticulture and Non-Destructive Assessment of Fruit Attributes. Acta Hortic. 2016, 1119. [CrossRef]

27. Lordan, J.; Reginato, G.H.; Lakso, A.N.; Francescatto, P.; Robinson, T.L. Natural Fruitlet Abscission as Related To Apple Tree Carbon Balance Estimated With the Malusim Mode. Sci. Hortic. 2019, 247, 296-309. [CrossRef]

28. Lesueur, C.; Knittl, P.; Gartner, M.; Mentler, A.; Furelative Humidityacker, M. Analysis of 140 pesticides from conventional farming foodstuff samples after extractions with the modified QuECHERS method. Food Control 2008, 19, 906-914. [CrossRef]

29. Ramalho, J.C.; Rodrigues, A.P.; Semedo, J.N.; Pais, I.P.; Martins, L.D.; Simões-Costa, M.C.; Leitão, A.E.; Fortunato, A.S.; Batista-Santos, P.; Palos, I.M.; et al. Sustained Photosynthetic Performance of Coffea Spp. Under Long-Term Enhanced [ $\mathrm{CO}_{2}$ ]. PLoS ONE 2013, 8. [CrossRef]

30. Nemeskéry, E.; Sardi, É.; Kovács-Nagy, E.; Stefanavits Bányai, É.; Nagy, J.; Nyéki, J.; Szabó, T. Studies on the Drough Responses of Apple Trees (Malus domestica Borkh.) Grafted on Different Rootstocks. Int. J. Hortic. Sci. 2009, 15, 29-36. [CrossRef]

31. Locatelli, G.; Pio, R.; Rayane, B.B.; Souza, F.B.M.; Castro, E.M.; Zambon, C.R. Leaf Anatomy of Apple Trees during Seasonal Periods under Subtropical Conditions. HortScience 2019, 54, 1887-1895. [CrossRef]

32. Byers, R. Influence of Temperature and Darkness on Apple Fruit Abscission and Chemical Thinning. J. Tree Prod. 2002, 3, 41-53. [CrossRef]

33. Brunner, P. Impact of Metamitron as a Thinning Compound on Apple Plants. Proc. XII ${ }^{\text {th }}$ IS on Plant Bioregulators in Fruit Production. Acta Hortic. 2014, 1042, 173-182. [CrossRef]

34. Gabardo, G.; Kretzschmar, A.; Petri, J.; Couto, M.; Hawerooth, F.; Silva, C. Taxa Fotossintética em Macieiras Tratadas com Metamitron. Rev. Elet. Cient. UERGS 2017, 3, 617-633. [CrossRef]

35. Stander, O.P.J.; Botes, J.; Krogscheepers, C. The Potential Use of Metamitron as a Chemical Fruit-Thinning Agent in Mandarin. HortTechnology 2018, 28, 28-34. [CrossRef] 
36. MacNeill, G.J.; Mehrpouyan, S.; Minow, M.A.A.; Patterson, J.A.; Tetlow, I.J.; Emes, M.J. Starch as a souce, starch as a sink: The bifunctional role of starch in carbon allocation. J. Exp. Bot. 2017, 68, 4433-4453. [CrossRef] [PubMed]

37. Dong, S.; Beckles, D.M. Dynamic changes in the starch-sugar interconversion with plant source and sink tissues promote a better abiotic stress response. J. Plant Physiol. 2019, 234, 80-93. [CrossRef] [PubMed]

38. Breen, K.; Tustin, S.; Palmer, J.; Boldingh, H.; Close, D. Revisiting the role of carbohydrate reserves in fruit set and early-season growth of apple. Sci. Hortic. 2020, 261. [CrossRef]

39. Petri, J.P.; Couto, M.; Gabardo, G.C.; Francescatto, P.; Hawerroth, F.J. Metamitron Replacing Carbaryl in Post Bloom Thinning of Apple Trees. Rev. Bras. Frutic. 2016, 38. [CrossRef]

Publisher's Note: MDPI stays neutral with regard to jurisdictional claims in published maps and institutional affiliations.

(C) 2020 by the authors. Licensee MDPI, Basel, Switzerland. This article is an open access article distributed under the terms and conditions of the Creative Commons Attribution (CC BY) license (http://creativecommons.org/licenses/by/4.0/). 